\title{
Age and sexual diVerences in the exploitation of two anthropogenic food resources for an opportunistic seabird
}

\author{
Joan Navarro $\cdot$ Daniel Oro $\cdot$ Albert Bertolero \\ Meritxell Genovart · Antonio Delgado · \\ Manuela G. Forero
}

\begin{abstract}
The availability of food resources has been suggested as a major factor in the substantial increase in reproductive output, survival, recruitment and, ultimately, population growth rates in most organisms. In fact, the artiWcial increase in food availability resulting from human activities has been suggested as a factor in the substantial increase in population size of several seabirds in recent decades. In the present study, our primary aim was to estimate the importance of the main natural prey and two alternative feeding resources, Wshery discards and the invasive American crayWsh Procambarus clarkii, for an opportunistic seabird, the Audouin's gull Larus audouinii. We also assessed the inXu-
\end{abstract}

Communicated by S. Garthe.

J. Navarro · M. G. Forero

Department of Conservation Biology,

Estación Biológica de Doñana, CSIC,

Av. Américo Vespucio, s/n, 41092 Sevilla, Spain

D. Oro $\cdot$ M. Genovart

Institut Mediterrani d’Estudis Avançats, IMEDEA (CSIC-UIB),

C/Miquel Marqués 21, 07190 Esporles, Majorca, Spain

A. Bertolero

IRTA Ecosistemes Aquàtics,

Sant Carles de la Ràpita, Carretera de Poble Nou km 5,

43540 Sant Carles de la Ràpita, Spain

\author{
A. Delgado \\ Laboratorio de Biogeoquímica de Isótopos Estables, \\ Instituio Andaluz de Ciencias de la Tierra, CSIC, \\ Present Address: \\ J. Navarro (\&) \\ Institute of Marine Science (ICM-CSIC), \\ Passeig Marítim de la Barceloneta 27-49, \\ 08003 Barcelona, Spain \\ e-mail: joan@icm.csic.es
}

Camino del Jueves s/n, 18100 Armilla, Granada, Spain ence of age and sex in the use of those three types of food. For this purpose, we compared the analyses of $\&^{15} \mathrm{~N}$ and $\&^{13} \mathrm{C}$ in blood of male and female adults of known age and chicks with those in their potential prey. Our results reveal sexrelated and age-related diVerences in the consumption of Wsh discards, small pelagic Wsh and American crayWsh. DiVerences in the diet of males and females and also between adults and chicks could be related to diVerent nutritional requirements. Age diVerences were probably related to their diVerent foraging proWciency and the tendency of young breeders to opportunistically exploit anthropogenically derived food. This study illustrates the importance of considering the age and sex of individuals to obtain feasible dietary information and to understand how the exploitation of food of human origin could aVect population growth.

\section{Introduction}

The availability of food resources has been described as a major factor inXuencing reproductive output, survival, recruitment and, ultimately, population growth rates in most species (e.g. Sinclair and Krebs 2003; Oro et al. 2004, 2008; Rutz and Bijlsma 2006). This is especially apparent in opportunist predators situated at the top of trophic networks, such as most seabird species (e.g. Cairns 1992; Furness 2003; Votier et al. 2008). Indeed, the artiWcial increase in the availability of trophic resources resulting from human activities, such as Wsheries discards, refuse dumps or introduced prey species, has been suggested as a factor in the substantial increase in population sizes of several seabirds in recent decades (e.g. Garthe et al. 1996; Oro et al. 2004; Tablado et al. 2010).

A clear example is the case of the Audouin's gull Larus audouinii. During the 1970s, it was one of the 
most endangered seabirds in the world (Burger and Gochfeld 1996). Since then, its world population has experienced a dramatic growth as a result of the increase in breeding site protection and the exploitation of feeding resources of human origin (Oro and Ruxton 2001). Although Audouin's gull is considered an evolutionarily adapted specialist in the capture of clupeiforms (e.g. they show nocturnal vision, see Oro 1998 and references therein), it can also eYciently exploit Wshery discards and terrestrial prey (e.g. Oro and Ruiz 1997; Oro et al. 1996a, 1997). It is also known that the diVerential exploitation of those preys could inXuence its breeding and feeding performance (Oro et al. 1996b, 1999, 2004). However, the available information of the actual value of these artiWcial resources in relation to age or sex of breeding adults is scarce and inaccurate. For instance, chicks of Audouin's gulls are fed with diVerent prey compared with that consumed by parents (Pedrocchi et al. 1996). Age and experience of breeding adults could also be important factors aVecting food exploitation (Ezard et al. 2007; Limmer and Becker 2009). Similarly, males and females diVer in their nutritional requirements depending on the breeding period: during egg formation, Wsheries discards do not necessarily meet the required energetic demand of females (Williams 2005; Navarro et al. 2009).

Today, the combination of data from long-term monitoring programs with new methodologies for the study of trophic habits is an eVective tool for estimating the true importance of those aforementioned anthropogenic resources for diVerent individuals in the population (i.e. Navarro et al. 2009). The stable isotope approach can complement and improve common means of dietary analysis since it reXects time-integrated dietary records and, thus, eliminates some of the shortcomings of traditional dietary studies, particularly when used in combination with the stable isotope values of potential prey (Forero and Hobson 2003). For marine ecosystems, $\&^{13} \mathrm{C}$ and $\&^{15} \mathrm{~N}$ values can discriminate the type of food consumed in relation to their benthic and pelagic origin (Forero and Hobson 2003; Navarro et al. 2009) or the use of marine or terrestrial food (Ramos et al. 2009). Moreover, by combining stable isotopic values of the consumers and their potential prey, isotopic mixing models can be applied to obtain estimates of the relative contribution of each potential prey to the diets of the consumer (Jackson et al. 2009).

Here, our aim was to estimate the importance of three feeding resources for Audouin's gulls breeding at their largest colony. Those three resources include the primary natural prey for Audouin's gull (i.e. small pelagic Wsh) and two alternative prey: demersal Wsh (a proxy of trawling Wshery discards) and a terrestrial prey (the American crayWsh Procambarus clarkii). Prey from rice Welds (such as crayWsh) act as a buVer against bad environmental conditions at sea and constitute an alternative foraging resource allowing birds from that population to increase their breeding performance (Oro et al. 1996a). We estimated the contribution of those prey types to the diet of male and female adults, adults of diVerent ages and small and large chicks using recent Bayesian isotope models (SIAR model, Jackson et al. 2009). For that purpose, we compared the $\&^{15} \mathrm{~N}$ and $\&^{13} \mathrm{C}$ values in blood of male and female adults of known ages and chicks with those of their potential food. Even though previous information about the inXuence of sex and age on diet of seabirds is scarce, here we can test the following hypotheses: foraging segregation between males and females should be low since sexual dimorphism in Audouin's gull is very low (but see Gray and Hamer 2001); it is also expected that chicks will be fed with prey of a higher energetic content (in our case, small pelagic Wsh) than those consumed by adults (Pedrocchi et al. 1996; Forero et al. 2002; Navarro et al. 2009). In relation to age of adults, we predict that younger breeders, with lower foraging experience, will more frequently exploit opportunistic foods, such as trawling discards and/or American crayWsh, than small pelagic Wsh, their natural prey (MacLean 1986; RatcliVe et al. 1998).

\section{Materials and methods}

\section{Study area and sampling procedure}

The study was conducted during 2003 at the reserve of Punta de la Banya, in the Ebro Delta Natural Park, northwestern Mediterranean $\left(40^{\circ} 33^{\prime} \mathrm{N}, 0^{\circ} 39^{\prime} \mathrm{E}\right)$. The Punta de la Banya is a Xat, sandy salt marsh of 2514 ha, partially occupied by saltworks, next to extensive rice Weld areas (20000 ha). This location holds around 12,000-13,000 breeding pairs of Audouin's gull, approximately $60 \%$ of the world population. The marine ecosystem of the Ebro Delta is one of the most important Wshing grounds in the Mediterranean Sea, resulting in one of the largest Wshing Xeets in this region, generating a high availability of Wsheries discards, mainly from trawlers (Coll et al. 2008). Moreover, during the early 1980s, the invasive American crayWsh, a crustacean native to south-eastern United States and northeastern Mexico, was introduced in the rice Weld areas of the Ebro Delta (Gutierrez-Yurrita et al. 1999).

During the incubation period of 2003, we sampled 50 breeding adults (30 males and 20 females). Later, during the post-hatching period (between 15 and 30 days after the incubation period), 29 small chicks (less than 15 days old) and 28 large chicks (more than 40 days old) were sampled. Both incubating adults and chicks were captured at their nests by nest traps and by hand, respectively. We determined the age of 35 of the 50 sampled adults because they were previously ringed as chicks, such ages ranging from 
4 to 17 years old. From each individual, we took $0.1 \mathrm{ml}$ of blood from the brachial vein. The blood was stored in $70 \%$ ethanol at room temperature until stable isotope analyses. A subsample of blood was also used for determining the sex of adults by molecular procedures (Ellegren 1996).

\section{Stable isotopes analyses}

Ethanol was removed from blood samples prior to analysis by decanting and freeze-drying. All samples (about $0.5-1$ $\mathrm{mg}$ ) were combusted at $1020^{\circ} \mathrm{C}$ using a continuous-Xow isotope-ratio mass spectrometry (CFIRMS) system by means of a Carlo Erba 1500NC elemental analyser interfaced with a Delta Plus XL mass spectrometer. All isotope abundances are expressed in \&-notation as parts per thousand $(\%)$ deviation from the IAEA standards AIR $\left(\&^{15} \mathrm{~N}\right)$ and VPDB $\left(\&^{13} \mathrm{C}\right)$. Based on within-run replicate measurements of laboratory standards (urea, shark cartilage), we estimated measurement error to be $\S 0.2 \%$ and $\S 0.1 \%$ for $\&^{15} \mathrm{~N}$ and $\&^{13} \mathrm{C}$ values, respectively.

\section{Isotopic mixing model}

Dietary composition of breeding adults (males, females and adults of diVerent age) and chicks (small and large chicks) was estimated based on their isotopic values and those of their potential prey. To estimate the contribution of diVerent prey, we adopted a Bayesian multi-source stable isotope mixing model, SIAR (see Jackson et al. 2009 for more details). We used published reference values for demersal and small pelagic Wsh from the Ebro Delta area during year 2003 (Fig. 1, demersal Wsh: $\quad \&^{15} \mathrm{~N}=9.54 \S 1.39 \%$, $\&^{13} \mathrm{C}=$ i 18.19 § $0.76 \%, \quad n=51 ; \quad$ small pelagic Wsh: $\&^{15} \mathrm{~N}=7.95 \S 1.08 \%$ o, $\quad \&^{13} \mathrm{C}=$ i $18.99 \S 0.71 \%, \quad n=39$; Navarro et al. 2009) and unpublished values for American crayWsh from the Ebro Delta rice Welds sampled during the year 2003 (Fig. $1, \&^{15} \mathrm{~N}=8.27 \S 2.21 \%, \&^{13} \mathrm{C}=$ i $27.73 \S$ $1.56 \%, n=20$; authors' unpublished data). To build the SIAR mixing model, we used diet-blood isotopic fractionation values between prey and blood of $2.91 \%$ for $\&^{15} \mathrm{~N}$ and $1.15 \%$ for $\&^{13} \mathrm{C}$ (see Caut et al. 2009).

\section{Statistical analyses}

We used ANOVA tests to examine the diVerences in both $\&^{15} \mathrm{~N}$ and $\&^{13} \mathrm{C}$ values among small chicks, large chicks, adult males and adult females. Post hoc comparisons were tested with a Tukey's test. We performed general linear models (GLM) using GENMOD procedure (SAS 1997) to analyze variations in stable isotopes with age of adults. Age and sex of adults and their interaction were Wtted to the stable isotope values applying a normal error and identity link function. The Bayesian mixing model was Wtted using R software (R Development Core Team 2005).

\section{Results}

Isotopic analysis for diVerent age and sex classes

$\&^{15} \mathrm{~N}$ and $\&^{13} \mathrm{C}$ values diVered among small chicks, large chicks, adult males and adult females (Fig. $1 . \&^{15} \mathrm{~N}: F_{3}$, $\left.{ }_{106}=31.31, P<0.0001 ; \&^{13} \mathrm{C}: F_{3,106}=8.64, P<0.0001\right)$. In particular, large chicks showed lower $\&^{15} \mathrm{~N}$ values than small chicks, adult males and adult females (Fig. 1, Tukey test, all $P<0.05)$. Small chicks showed lower $\&^{15} \mathrm{~N}$ values than adult males (Fig. 1, Tukey test, $P<0.05$ ) and similar $\&^{15} \mathrm{~N}$ values to adult females (Fig. 1 , Tukey test, $P=0.18$ ). Regarding $\&^{13} \mathrm{C}$ values, small chicks showed lower values than large chicks and adult males (Fig. 1, all Tukey tests $P<0.05$ ) and similar values to adult females (Fig. 1, Tukey test, $P=0.99)$. Adult females showed lower $\&^{13} \mathrm{C}$ values than adult males and large chicks (Fig. 1, all Tukey tests $P<0.05)$. Adult males and females diVered in both their $\&^{15} \mathrm{~N}$ and $\&^{13} \mathrm{C}$ values, with males showing higher values of both isotopes (Fig. $1 . \&^{15} \mathrm{~N}: F_{1,50}=1.85, P=0.01 ; \&^{13} \mathrm{C}: F_{1}$, ${ }_{50}=6.57, P=0.01$ ).

When analyzing the eVect of age on stable isotope values of adults and subsequently including the signiWcant eVect of sex, we obtained two models that included the signiWcant eVect of age on the $\&^{13} \mathrm{C}$ values (sex: $z^{2}=4.04, d f=1,33$, $P=0.04$; age: $\left.z^{2}=6.37, d f=1,33, P=0.01\right)$ and the $\&^{15} \mathrm{~N}$ values (sex: $z^{2}=5.95, d f=1,33, P=0.01$; age: $z^{2}=4.03$,

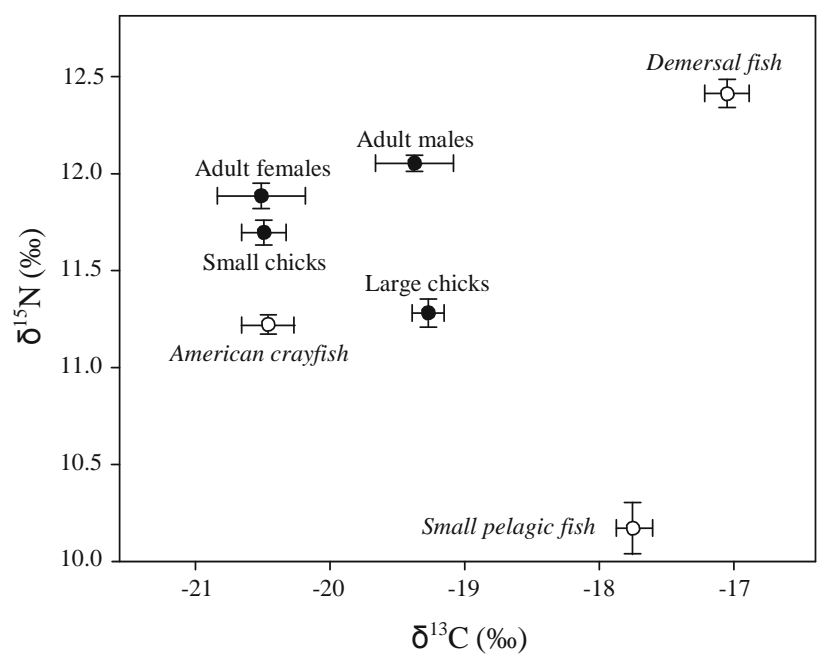

Fig. 1 Blood $\&^{15} \mathrm{~N}$ and $\&^{13} \mathrm{C}$ values (mean § SE) of 29 small chicks, 28 large chicks and 50 breeding adults (20 males and 30 females) of Audouin's gull sampled at the Ebro Delta area. White points correspond to potential prey groups sampled in the Ebro Delta area (demersal Wsh and small pelagic Wsh from Navarro et al. 2009; American crayWsh from the present study) 
$d f=1,33, P=0.04)$. These models explained 24 and $25 \%$ of the original deviance on stable isotopes of nitrogen and carbon, respectively. Older male and female adults showed lower and higher levels of $\&^{15} \mathrm{~N}$ and $\&^{13} \mathrm{C}$ values, respectively.

Dietary diVerences among individuals of diVerent age and sex classes

The proportion of each potential prey, estimated by SIAR models, varied in relation to the age and sex of Audouin's gull in the Ebro Delta area (Fig. 2). The diet of adult males was composed mostly of demersal Wsh (mean of the credibility interval: 48\%), followed by small pelagic Wsh (30\%) and then American crayWsh (20\%). In contrast, the SIAR mixing model revealed that females included a similar proportion of small pelagic Wsh (29\%), demersal Wsh (39\%) and American crayWsh (31\%) in their diets (Fig. 2).

The diet of small chicks was similar to the diet of adult females, composed of demersal Wsh (34\%), small pelagic Wsh (34\%) and American crayWsh (32\%). For large chicks, the diet was mainly composed of small pelagic Wsh (53\%), followed by demersal Wsh (28\%) and American crayWsh (19\%). The SIAR isotopic mixing model estimated that the diet of individuals between 4 and 10 years old was composed of a similar proportion of the three potential prey groups: demersal Wsh (28-39\%), small pelagic Wsh (27-33\%) and American crayWsh (26-44\%) (Fig. 3). However, adults from 11 to 17 years old consumed mainly demersal (36-43\%) and small pelagic Wsh (35-37\%) and, to a lesser extent, American crayWsh (19-28\%) (Fig. 3).



Fig. 2 Results of SIAR (95, 75 and 50\% credibility intervals) showing estimated prey contributions to the diet of adults, small chicks and large chicks of Audouin's gulls sampled in the Ebro Delta area during the year 2003. Dem (Demersal Wsh); Pel (Small pelagic Wsh); Cray (American crayWsh)

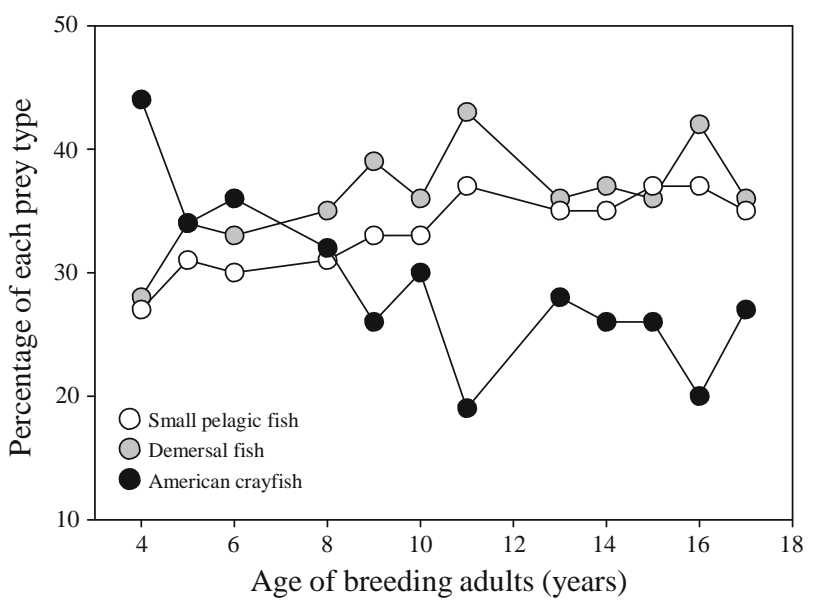

Fig. 3 Mean percentage of the contribution of small pelagic Wsh, demersal Wsh and American crayWsh in the diet of adults of Audouin's gulls sampled in the Ebro Delta area during the year 2003 in relation to their age (between 4 and 17 years old) estimated from Bayesian mixing models (SIAR)

\section{Discussion}

In this work, we show the diVerential importance of two anthropogenic food resources, demersal Wsh (i.e. Wsheries discards) and the invasive American crayWsh, and a natural resource, the small pelagic Wsh, for the Audouin's gull. DiVerences in the diet of incubating adults and chicks and also between males and females could be related to diVerent nutritional requirements. Age-related variation in the use of these trophic resources was probably associated with variations in the foraging abilities of adults of diVerent ages (i.e. intra- and interspeciWc competition in the feeding areas). The diVerence in the diet between adults and chicks probably was related to a diVerential nutritional requirement of the food consumed. These results illustrate the importance of considering diVerent ages and sexes of a breeding population to obtain feasible dietary information and to understand the relative importance of the diVerent food resources.

It is well documented that opportunist seabirds take advantage of Wsheries even at great distances from their breeding colonies, feeding on discarded Wsh and oVal (e.g. Furness and Tasker 2000; Arcos and Oro 2002b; Votier et al. 2008). In our case and in concordance with previous studies (Oro et al. 1997; Arcos et al. 2001; Pedrocchi et al. 2002; Sanpera et al. 2007), the SIAR isotopic mixing model also estimated the presence of demersal Wsh, only available through Wsheries discards, in the diet of incubating adults and chicks at the Ebro Delta. Nonetheless, the SIAR results also revealed that the introduced American crayWsh was an important food resource for the Audouin's gull in the Ebro Delta area. This resource has been 
previously reported as an important alternative prey not only for Audouin's gulls, but also for yellow-legged Larus michahellis and lesser black-backed gulls $L$. fuscus from the Ebro Delta, particularly when marine resources were not readily available (Bosch et al. 1994; Oro et al. 1996a, 1997; Oro 1996).

The importance of these two anthropogenic food resources varied according to the age and sex of individuals. Lower $\&^{13} \mathrm{C}$ and $\&^{15} \mathrm{~N}$ values of adult females in relation to adult males and the results from the isotopic mixing model indicated a higher proportion of American crayWsh in the diet of females than in males. Mañosa et al. (2004) found that females spent more time than males outside of the colony, suggesting that foraging at the rice Welds might have the advantage of reducing competition (Arcos et al. 2001) but that encounter rates with the crayWsh would be rather low (authors' personal observations). It is also known that during the courtship feedings, males feed females and that such feedings are composed mainly by Wsh (Oro 1998). This diVerence in the diet between males and females might be the consequence of diVerential nutritional requirements of both sexes relating to egg formation (Williams 2005). During the formation of the egg, besides lipids and proteins, females need a high amount of carotenoids (Blount et al. 2001, 2004), a micronutrient present in high concentration in the American crayWsh (Negro et al. 2000). For this reason, although the nutritional value of crustaceans is, in general, lower than that of marine Wsh (Massias and Becker 1990; Arcos and Oro 2002a), the high availability of the American crayWsh at the Ebro Delta (Gutierrez-Yurrita et al. 1999) and its high content of carotenoids could confer a reproductive beneWt to the females that consume such prey.

Similarly, the present study revealed that young adults (from 4 to 10 years old) included in their diet the three prey groups considered (small pelagic Wsh, demersal Wsh and American crayWsh) in a similar proportions, whereas older birds (from 11 to 17 years old) mainly consumed small pelagic and demersal Wsh. For long-lived seabirds, feeding abilities and foraging performance should increase with age (Ezard et al. 2007; Limmer and Becker 2009). Due to their reduced ability and experience, young adults are less proWcient foragers and they could be limited to feeding on easy and usually less proWtable food (Daunt et al. 1999; Limmer and Becker 2009). At the Ebro Delta, there is a high intra- and interspeciWc competition for the use of Wsheries discards, a proWtable food, by seabirds (Arcos et al. 2001; González-Solís et al. 1997; Martínez-Abraín et al. 2003; Skórka and Wójcik 2008). Probably, the lower competitive ability of young adults precludes them from feeding often on trawling discards, and the American crayWsh may represent an alternative foraging resource that may act as a buVer for this constraint, allowing young breeders to enhance their breeding performance (Oro et al. 1996b).

In the case of small chicks, their stable isotope values and the proportion of consumed prey estimated by the isotopic mixing model were quite similar to adult females during incubation. Stable isotope values of whole blood represent the diet during the month prior to blood sampling (Bearhop et al. 2002; Pearson et al. 2003). For this reason, and as we sampled 15-day-old chicks, stable isotopes were partially reXecting the diet of females during egg formation (Hobson 1995). Alternatively, in the case of large chicks, we found that their diet was diVerent from the diet of adults during the incubation period, who fed them mainly on small pelagic Wsh and a low proportion of demersal species and American crayWsh. Two factors likely explain the high representation of pelagic Wsh in the diet of growing chicks: the nutritional value of these species and food availability. Previous studies have shown that adults of Audouin's gulls fed their large chicks mainly on anchovies and pilchards (Pedrocchi et al. 1996), pelagic Wsh with a higher nutritional value than demersal Wsh and crustaceans (Massias and Becker 1990; Arcos and Oro 2002a; Grémillet et al. 2008). In fact, in other gull species, a positive relationship has been found between the percentage of Wsh in the diet of chicks and breeding success (Pierotti 1982; Murphy et al. 1984; Sydeman et al. 1991). Additionally, the chick-rearing period of Audouin's gull also coincides with the increase in the natural abundance of small pelagic Wsh during MayJune at the Ebro Delta (Lloret et al. 2004).

In conclusion, this study shows that natural prey (small pelagic Wsh) are the main prey in the diet of the oVspring of the Audouin's gull in the Ebro Delta area. Moreover, other trophic resources of human origin, Wsheries discards and American crayWsh, are used by adults of a particular age and sex. The supply of Wsheries discards has been previously described as the main reason for the spectacular increase in the breeding population of the Audouin's gull at the Ebro Delta, with an average increase of $22 \%$ per annum over the last 28 years (Oro 1998; Oro and Ruxton 2001). In addition, we suggest that the presence of American crayWsh might also have contributed to this increase, by providing a trophic subsidy for the species, especially for young breeders and when marine resources were not available (Oro 1996; Oro et al. 1996a). This invasive crustacean was introduced during the early 1980s in the rice Weld areas of the Ebro Delta area for harvesting, in the same years that Audouin's gulls colonized the site. These results highlight the complexity of the impact of both invasive species (American crayWsh) and overharvesting (trawling Wsheries in the Mediterranean) in ecosystems, particularly when designing conservation guidelines. 
Acknowledgments The staV of the Ebro Delta NP and several volunteers, in special to Mario G. Dominguez, helped with logistics, including the ringing of gulls over the years. Laura Cardador provided valuable suggestions to improved previous versions of this manuscript. We would like to thank two anonymous reviewers for their valuable comments to improve this manuscript. Research funds were provided by the Spanish (REN2002-00450 and CGL2006-04325/BOS) and Andalucía Governments (P06-RNM-02362).

\section{References}

Arcos JM, Oro D (2002a) SigniWcance of Wsheries discards for a threatened Mediterranean seabird, the Balearic shearwater PuYnus mauretanicus. Mar Ecol Prog Ser 239:209-220

Arcos JM, Oro D (2002b) SigniWcance of nocturnal purse seine Wsheries for seabirds: a case study oV the Ebro Delta (NW Mediterranean). Mar Biol 141:277-286

Arcos JM, Oro D, Sol D (2001) Competition between yellow-legged gull Larus cachinnans and Audouin's gull Larus audouinii associated with commercial Wshing vessels: the inXuence of season and Wshing Xeet. Mar Biol 139:807-816

Bearhop S, Waldron S, Votier SC, Furness RW (2002) Factors that inXuence assimilation rates and fractionation of nitrogen and carbon stable isotopes in avian blood and feathers. Physiol Biochem Zool 75:451-458

Blount JD, Surai PF, Nager RG, Houston DC, Moller AP, Trewby ML, Kennedy MW (2001) Carotenoids and egg quality in the lesser black gull Larus fuscus: a supplemental feeding study of maternal eVects. P Roy Soc B-Biol Sci 269:29-36

Blount JD, Houston DC, Surai PF, Moller AP (2004) Egg-laying capacity is limited by carotenoid pigment availability in wild gulls Larus fuscus. P Roy Soc B-Biol Sci 271:79-81

Bosch M, Oro D, Ruiz X (1994) Dependence of Yellow-legged Gulls (Larus cachinnans) on food from human activity in two Western Mediterranean colonies. Avocetta 18:135-139

Burger J, Gochfeld M (1996) Family Laridae (Gulls). In: Del Hoyo J, Sargatal J (eds) Handbook of the birds of the world. Lynx Edicions, Barcelona

Cairns DK (1992) Population regulation of seabird colonies. In: Power DM (ed) Current ornithology. Kluwer/Plenum, Dordrecht

Caut S, Angulo E, Courchamp F (2009) Variation in discriminant factors $\left(\&^{15} \mathrm{~N}\right.$ and $\left.\&^{13} \mathrm{C}\right)$ : the eVect of diet isotopic values and applications for diet reconstruction. J Appl Ecol 46:443-453

Coll M, Palomera I, Tudela S, Dowd M (2008) Food-web dynamics in the South Catalan Sea ecosystem (NW Mediterranean) for 19782003. Ecol Model 217:95-116

Daunt F, Wanless S, Harris MP, Monaghan P (1999) Experimental evidence that age-speciWc reproductive success is independent of environmental eVects. P Roy Soc B-Biol Sci 266:14891493

Ellegren H (1996) First gene on avian W chromosome (CHD) provides a tag for universal sexing of non-ratite birds. P Roy Soc B-Biol Sci 263:1635-1641

Ezard TH, Becker PH, Coulson T (2007) The correlation between age, phenotypic traits and reproductive success in common terns (Sterna hirundo). Ecology 88:2496-2504

Forero MG, Hobson KA (2003) Using stable isotopes of nitrogen and carbon to study seabird ecology: applications in the Mediterranean seabird community. Sci Mar 67:23-32

Forero MG, Hobson KA, Bortolotti GR, Donázar JA, Bertellotti M, Blanco G (2002) Food resource utilisation by the Magellanic penguin evaluated through stable-isotope analysis: segregation by sex and age and inXuence on oVspring quality. Mar Ecol Prog Ser 234:289-299
Furness RW (2003) Impacts of Wsheries on seabird communities. ICES J Mar Sci 68:1193-1206

Furness RW, Tasker ML (2000) Seabird-Wshery interactions: quantifying the sensitivity of seabirds to reductions in sandeel abundance, and identiWcation of key areas for sensitive seabirds in the North Sea. Mar Ecol Prog Ser 202:253-264

Garthe S, Camphuysen CJ, Furness RW (1996) Amounts of discards by commercial Wsheries and their signiWcance as food for seabirds in the North Sea. Mar Ecol Prog Ser 136:1-11

González-Solís J, Oro D, Jover L, Ruiz X, Pedrocchi V (1997) Trophic niche width and overlap of two sympatric gulls in the southwestern Mediterranean. Oecologia 112:75-80

Gray CM, Hamer KC (2001) Food- provisioning behaviour of male and females Manx shearwaters, PuYnus puYnus. Anim Behav 62:117-121

Grémillet D, Pichegru L, Kuntz G, Woakes AG, Wilkinson S, Crawford RJM, Ryan PG (2008) A junk-food hypothesis for gannets feeding on Wshery waste. P Roy Soc B-Biol Sci 275:1149-1156

Gutierrez-Yurrita PJ, Martínez JM, Ilhéu M, Bravo-Utrera MA, Bernardo JM, Montes C (1999) The status of crayWsh populations in Spain and Portugal. In: Gerardi F, Holdich D (eds) CrayWsh in Europe as Alien Species: How to Make the Best of a Bad Situation? Crustacean Issues. Balkema, Rotterdam

Hobson KA (1995) Reconstructing avian diets using stable-carbon and nitrogen isotope analysis of egg components: patterns of isotopic fractionation and turnover. Condor 97:752-762

Jackson AL, Inger R, Bearhop S, Parnell A (2009) Erroneus behaviour of MixSIR, a recently published Bayesian isotope mixing model: a discussion of Moore \& Seemens (2008). Ecol Lett 12:E1-E5

Limmer B, Becker PH (2009) Improvement in chick provisioning with parental experience in a seabird. Anim Behav 77:1095-1101

Lloret J, Palomera I, Salat J, Sole I (2004) Impact of freshwater input and wind on landings of anchovy (Engraulis encrasicolus) and sardine (Sardina pilchardus) in shelf waters surrounding the Ebre (Ebro) River delta (north-western Mediterranean). Fish Oceanogr 13:102-110

MacLean AAE (1986) Age-speciWc foraging ability and the evolution of deferred breeding in three species of gulls. Wilson J Ornithol 98:267-279

Mañosa S, Oro D, Ruiz X (2004) Activity patterns and foraging behaviour of Audouin's gulls in the Ebro Delta, NW Mediterranean. Sci Mar 68:605-614

Martínez-Abraín A, González-Solís J, Pedrocchi V, Genovart X, Abella JC, Ruiz X, Jiménez J, Oro D (2003) Kleptoparasitism, disturbance and predation of yellow-legged gulls on Audouin's gulls in three colonies of the western Mediterranean. Sci Mar 67:89-94

Massias A, Becker PH (1990) Nutritive value of food and growth in common tern Sterna hirundo. Ornis Fennica 21:187-194

Murphy EC, Day RH, Oakley KL, Hoover AA (1984) Dietary changes and poor reproductive performance in glaucous-winged gulls. Auk 101:532-541

Navarro J, Louzao M, Igual JM, Oro D, Delgado A, Arcos JM, Genovart M, Hobson KA, Forero MG (2009) Seasonal changes in the diet of a critically endangered seabird and the importance of trawling discards. Mar Biol 156:2571-2578

Negro JJ, Tella JL, Blanco G, Forero MG, Garrido-Fernandez J (2000) Diet explains interpopulation variation of plasma carotenoids and skin pigmentation in nestling white storks. Physiol Biochem Zool 73:97-101

Oro D (1996) The eVects of trawler discard availability on the egglaying and the breeding success of the Lesser Black-backed Gull Larus fuscus in western Mediterranean. Mar Ecol Prog Ser 132:43-46

Oro D (1998) Larus audouinii Audouin’s Gull. BWP Update. Oxford University Press, Oxford 
Oro D, Ruiz X (1997) Exploitation of trawler discards by breeding seabirds in the north-western Mediterranean: diVerences between the Ebro Delta and the Balearic Islands areas. ICES J Mar Sci 54:695-707

Oro D, Ruxton GD (2001) The formation and growth of seabird colonies: Audouin's gull as a case study. J Anim Ecol 70:527-535

Oro D, Genovart X, Ruiz X, Jimenez J, Garcia-Gans J (1996a) DiVerences in diet, population size and reproductive performance between two colonies of Audouin's gull Larus audouinii aVected by a trawling moratorium. J Avian Biol 27:245-251

Oro D, Jover L, Ruiz X (1996b) InXuence of trawling activity on the breeding ecology of a threatened seabird, Audouin's gull Larus audouinii. Mar Ecol Prog Ser 139:19-29

Oro D, Ruiz X, Jover L, Pedrocchi V, González-Solís J (1997) Diet and adult time budgets of Audouin's Gull Larus audouinii in response to changes in commercial Wsheries. Ibis 139:631-637

Oro D, Pradel R, Lebreton JD (1999) Food availability and nest predation inXuence life history traits in Audouin's gull, Larus audouinii. Oecologia 118:438-445

Oro D, Cam E, Pradel R, Martínez-Abraín A (2004) InXuence of food availability on demography and local population dynamics in a long-lived seabird. P Roy Soc B-Biol Sci 271:387-396

Oro D, Margalida A, Carrete M, Heredia R, Donázar JA (2008) Testing the goodness of supplementary feeding to enhance population viability in an endangered vulture. Plos One 3:e4084

Pearson SF, Levey DJ, Greenberg CH, Martínez del Rio C (2003) EVects of elemental composition on the incorporation of dietary nitrogen and carbon isotopic signatures in an omnivorous songbird. Oecologia 135:516-523

Pedrocchi V, Oro D, González-Solís J (1996) DiVerences between diet of adult and chick Audouin's Gulls Larus audouinii at the Chafarinas Islands, SW Mediterranean. Ornis Fennica 73:124-130

Pedrocchi V, Oro D, González-Solís J, Ruiz X, Jover L (2002) DiVerences in diet between the two largest breeding colonies of Audouin's gulls: the eVect of Wshery activities. Sci Mar 66:313-320
Pierotti R (1982) Habitat selection and its eVects on the reproductive output in the herring gull in Newfoundland. Ecology 63:854-868

R Development Core Team (2005) R: a language and environment for statistical computing. R Foundation for Statistical Computing, Vienna

Ramos R, Ramírez F, Sanpera C, Jover L, Ruiz X (2009) Feeding ecology of yellow-legged gulls (Larus michahellis) in the western Mediterranean: a comparative assessment using conventional and isotopic methods. Mar Ecol Prog Ser 377:289-297

RatcliVe N, Furness RW, Hamer KC (1998) The interactive eVects of age and food supply on the breeding ecology of great skuas. J Anim Ecol 67:853-862

Rutz C, Bijlsma RG (2006) Food-limitation in a generalist predator. P Roy Soc B-Biol Sci 273:2069-2073

Sanpera C, Moreno C, Ruiz X, Jover L (2007) Audouin's gull chicks as bioindicators of mercury pollution at diVerent breeding locations in the western Mediterranean. Mar Pollut Bull 54:691-696

Sinclair ARE, Krebs CJ (2003) Complex numerical responses to topdown and bottom-up processes in vertebrate populations. In: Sibly RM, Hone J, Clutton-Brock T (eds) Wildlife population growth rates. Cambridge University Press, Cambridge

Skórka P, Wójcik JD (2008) Habitat utilisation, feeding tactics and age related feeding eYciency in the Caspian gull Larus cachinnans. J Ornithol 149:31-39

Sydeman WJ, Penniman JF, Penniman TM, Pyle P, Ainley DG (1991) Breeding performance in the western gull: eVect of parental age, timing of breeding and year in relation to food availability. J Anim Ecol 60:135-149

Tablado Z, Tella JL, Sánchez-Zapata JA, Hiraldo F (2010) The paradox of the long-term positive eVects of a North American crayWsh on a European community of predators. Conserv Biol (in press)

Votier SC, Bearhop S, Fyfe R, Furness RW (2008) Temporal and spatial variation in the diet of a marine top predator-links with commercial Wsheries. Mar Ecol Prog Ser 267:223-232

Williams TD (2005) Mechanisms underlying the costs of egg production. Bioscience 55:39-48 